\title{
Estimation of digital protection devices applicability on basis of multiple characterizing parameters
}

\author{
Dimitar Bogdanov* \\ Technical University of Sofia (TUS), Faculty of electrical engineering, Chair "Electrical power engineering" \\ "Relay Protection" Laboratory
}

\author{
A R T I C L E I N F O \\ Article history: \\ Received: 17 November, 2017 \\ Accepted: 10 January, 2017 \\ Online: 30 January, 2018
}

\begin{tabular}{l}
\hline Keywords : \\
Electrical power system \\
Intelligent electronic device \\
(IED), protection devices, \\
Selection, raking, criteria
\end{tabular}

\begin{abstract}
A B S T R A C T
The contemporary electrical power systems (EPS) impose increased requirements for the functionality of the protection systems. The necessity of improved EPS stability is in some extent resulting of the increased integration of renewable sources of electrical energy. The future grid development gives perspective for connection of more converter based generations. The power electronic schemes and associated functional requirements impose necessity of high speed, sensitive, selective and reliable operation of the protection devices. These requirements have always been target of the protection equipment producers and grid operators. The electronic converting schemes specifics impose these requirements for the protection devices in more straightened way, as the converter connected generator may need to trip in shorter time than classical machine generator. In the article is presented a generalized overview of some of the characteristics of the digital "relay" protection devices, and approach for device selection is proposed. Investment planning may utilize such approach in order to have an optimal design from financial point of view.
\end{abstract}

\section{Introduction}

During the last decades the protection systems went through extensive technological advance. Practically the term "relay protection" becomes a bit obsolete, or depicting only the particular sector of automation of the EPS. There is a sustainable tendency more converter based generations to be grid connected [1]. Several cases of severe black-outs [2,3,4,5] imposed increased requirements in respect to EPS protection. The results of post-fault analysis for such events indicated, that normative documents in many countries were in some extent obsolete. In result many new rules and design principles were adopted to enhance the EPS stability, power quality improvement of operation and maintenance flexibility [6,7]. Cyber security is also an important issue for the contemporary EPS automation schemes, and in result of the tendency for transfer to digital technologies, this problem will stand for the future as well $[9,10,11]$. The electrical/electronic equipment vulnerability to other natural phenomena like extreme solar activity [10] also imposes challenges for the protection systems. "Magnetic storms/solar protuberances" have already impacted the operation of EPS protection and control systems

\footnotetext{
"Corresponding Author: Dimitar Bogdanov, Email: dbogdanov@tu-sofia.bg
}

[10]. The protection devices recordings for fault events can be a valuable source of data for the analysis of the pre-history and consequences of the event $[8,9,12]$.

The functionality of the "relay" protection systems can be observed from different aspects. The optimal design solution for particular scheme of protection system can be estimated by different indices as functional applicability, reliability, compatibility with site conditions, maintenance, MMI (ManMachine Interface) specifics, etc.

In order to achieve an optimal selection of protection devices / IEDs for particular application, object of interest is the characterizing criteria to be systematized and evaluated with "structured" approach. First of all such approach can help to create a "template form" for estimation equipment compliance with user's requirements. The elaboration of such approach may also ease the selection of equipment out of several alternatives. If preliminary set of requirements / criteria for protection equipment selection (or protection and control) is available, it can be systematized in groups with the respective listed characteristics.

The paper is based on study of 5 different vendors of digital protection devices / IEDs. All studied devices were tested for 
functional behavior: fault conditions were simulated, connected to PC with firmware for data transfer of settings, logs of events analyzed, etc. The samples of equipment were analyzed in laboratory conditions.

Each of the protection device characteristics can be assigned to a more generalized group, and in such manner they can be presented as:

1) Operational principle, functional applicability, applicability for the particular object (scheme);

2) Compliance with the respective standards, state /grid operator, utility/ requirements, and client's specific rules;

3) Reliability indices;

4) Self-test function, level of self-test, self-test signaling;

5) Overall construction - general characteristics;

6) Overall construction - internal structure;

7) Overall construction - set of functions (electrical, technological protections);

8) Intelligent Electronic Devices (IED) characteristics;

9) Installation location conditions compatibility;

10) Compatibility with power supply;

11) Compatibility with peripheral devices;

12) Firmware (software);

13) Man - machine interface (MMI) characteristics;

14) Interfaces to other systems;

15) Service time, without necessity of maintenance / servicing;

16) Data / event registration; "oscillographic" recorder functions /wave form records/;

17) Functionality to operate in centralized/decentralized systems for protection and control;

18) Functionality to receive (and redistribute) centralized synchronization;

19) Functionality to provide functions for Wide Area Protection (WAP), grid (EPS) level protection functions (load shedding, etc.);

20) Functionality for control of commutation apparatus, interlocking between devices, etc.;

21) Modular design, options for upgrade and extension;

22) Service life, guaranteed under the specified operating conditions;

23) Guaranteed period for service, procurement of spare parts, firmware update / support;

24) Unauthorized access protection;

25) References for application, other;

26) Financial aspects.

\section{Proposed method for estimation of digital protection devices applicability}

In result of study on the vendors proposed devices, the required characteristics and protection devices specifics by users / regulations, generalization was made. The above listed general characteristics (1-26) do not cover all possible categories to estimate the devices specifics. They are presented as general list of IED functionality features, but not pretending to envelope in completeness all applicable characteristics. The qualitative estimation of the level of fulfillment of the designer / investor requirements for each characteristic can be ranked as:

$$
e_{i}=\left\{0 \div r_{i}\right\}
$$

where $r_{i}$ is the maximal ranking for each characteristic. For the presented example list of 26 groups of generalized characteristics, for each group the value $E_{c}$ can be calculated. It can be calculated on basis of the sum of score ranking points $e_{i}$ for each subcharacteristic pertaining to the respective group:

$$
E_{c}=\sum_{i=1}^{n} e_{i}
$$

where $n$ is the number of grouped "sub-characteristics".

For equipment evaluation based on 26 generalized characterizing features, can be written:

$$
E_{S}=\sum_{j=1}^{m} E_{c j},
$$

Where $m$ for the presented set of characteristic groups is 26 .

In Table 1 is presented the set of characteristic groups, detailed in sub-characteristics. In the presented proposal for protection equipment estimation 26 groups are included, but definitely this number can be extended or limited in respect to the needed range. In the right column are presented the maximal ranking points, giving options to estimate the $100 \%$ criteria fulfillment. For "fulfillment" is assumed the operator's requirement, accomplishment to achieve the needed protection device

\begin{tabular}{|c|c|c|}
\hline $\mathbf{N}$ & $\begin{array}{l}\text { Characteristic (group of characterizing } \\
\text { parameters) / Sub-characteristics }\end{array}$ & $\mathbf{E c} / \mathbf{r}_{\mathbf{i}}$ \\
\hline \multirow[t]{5}{*}{1} & $\begin{array}{l}\text { Operational principle, functional applicability, } \\
\text { applicability by particular object (scheme) }\end{array}$ & 100 \\
\hline & $\begin{array}{l}\text { - Correspondence of the set of functions to } \\
\text { the protected object }\end{array}$ & 25 \\
\hline & $\begin{array}{l}\text { - Completeness of the set of functions in } \\
\text { respect to the necessary full set }\end{array}$ & 25 \\
\hline & $\begin{array}{l}\text { Applicability of the specific operational } \\
\text { principle to the object. Amicability for the } \\
\text { range of variation of the operating values. }\end{array}$ & 25 \\
\hline & $\begin{array}{l}\text { - Applicability of the device to the particular } \\
\text { technical parameters of the interfacing } \\
\text { connections }\end{array}$ & 25 \\
\hline \multirow[t]{3}{*}{2} & $\begin{array}{l}\text { Compliance with the respective standards and } \\
\text { regulations, state requirements /EPS operator } \\
\text { (TSO), utility/ and client's specific rules }\end{array}$ & 100 \\
\hline & $\begin{array}{l}\text { - Compliance with applicable international } \\
\text { standards and regulations }\end{array}$ & 50 \\
\hline & $\begin{array}{l}\text { - Compliance with applicable national / } \\
\text { client norms, rules and standards }\end{array}$ & 50 \\
\hline \multirow[t]{4}{*}{3} & Reliability indices & 200 \\
\hline & - MTTF (Mean Time To Failure) & 25 \\
\hline & - MTBF (Mean Time Between Failures) & 25 \\
\hline & - $\quad$ MTTR (Mean Time To Repair) & 25 \\
\hline
\end{tabular}
functionality.

Table 1 IED set of characteristic groups 


\begin{tabular}{|c|c|c|}
\hline \multirow[t]{3}{*}{$\mathbf{N}$} & $\begin{array}{l}\text { Characteristic (group of characterizing } \\
\text { parameters) / Sub-characteristics }\end{array}$ & $\mathbf{E c} / \mathbf{r}_{\mathbf{i}}$ \\
\hline & $\begin{array}{l}\text { MTTDF (Mean Time To Detect Failure) } \\
\text { /related also to self-test, annunciation/ }\end{array}$ & 25 \\
\hline & $\begin{array}{l}\text { POFTT (Probability of Fail to Trip) /can be } \\
\text { calculated on probabilistic basis, as } \\
\text { internally blocked by self-test relay may } \\
\text { fail to clear fault/ }\end{array}$ & $100^{*}$ \\
\hline \multirow[t]{5}{*}{4} & $\begin{array}{l}\text { Self-test function, level of self-test, self-test } \\
\text { signaling }\end{array}$ & 100 \\
\hline & - General hardware self-test & 30 \\
\hline & - Data processing self-test & 25 \\
\hline & $\begin{array}{l}\text { - Peripheral analog signal circuits self-test / } \\
\text { diagnostics }\end{array}$ & 25 \\
\hline & $\begin{array}{l}\text { External circuit supervision (trip, } \\
\text { measurement circuit, etc.) / diagnostics }\end{array}$ & 20 \\
\hline \multirow[t]{7}{*}{5} & Overall construction - general characteristics & 120 \\
\hline & $\begin{array}{l}\text { - Compatibility of the hardware construction } \\
\text { to intended place of installation }\end{array}$ & 35 \\
\hline & $\begin{array}{l}\text { Degree of protection (IP) of casing / } \\
\text { peripheral units / terminal strips } \\
\text { applicability }\end{array}$ & 20 \\
\hline & $\begin{array}{l}\text { - Stability of operating parameters in respect } \\
\text { to ambient conditions ranges }\end{array}$ & 20 \\
\hline & - Electromagnetic compatibility & 20 \\
\hline & - Seismic qualification & 15 \\
\hline & $\begin{array}{l}\text { - Thermal requirements / necessity of forced } \\
\text { ventilation / cooling, preheating etc. }\end{array}$ & 10 \\
\hline \multirow[t]{13}{*}{6} & Overall construction - internal structure & 140 \\
\hline & $\begin{array}{l}\text { Internal structure organization. Processing } \\
\text { boards (CPUs) number. Task managing for } \\
\text { calculation / operational memory optimal } \\
\text { resource utilization. }\end{array}$ & 20 \\
\hline & $\begin{array}{l}\text { Internal bus - type, parameters, } \\
\text { expandability. }\end{array}$ & 20 \\
\hline & $\begin{array}{l}\text { - Available type of peripheral boards, } \\
\text { parameters, interchangeability }\end{array}$ & 10 \\
\hline & - Processor(s) type, speed, productivity & 10 \\
\hline & - Bit range of the data bus & 10 \\
\hline & $\begin{array}{l}\text { - Operational memory (RAM), type, } \\
\text { installed capacity, maximal size }\end{array}$ & 10 \\
\hline & $\begin{array}{l}\text { - Absence of rotating parts in forced cooling } \\
\text { for CPU/other ICs }\end{array}$ & 10 \\
\hline & - $\mathrm{ADC}$ resolution & 10 \\
\hline & - Signal processor/type, characteristics/ & 10 \\
\hline & - Sampling rate of the measured quantities & 10 \\
\hline & $\begin{array}{l}\text { - Non-volatile support for memory / data } \\
\text { back-up in case of power interruption }\end{array}$ & 10 \\
\hline & $\begin{array}{l}\text { - EEPROM (flash memory) for data } \\
\text { recording / SSD }\end{array}$ & 10 \\
\hline \multirow[t]{3}{*}{7} & $\begin{array}{l}\text { Overall construction - set of functions } \\
\text { (electrical, technological protections) }\end{array}$ & 20 \\
\hline & $\begin{array}{l}\text { - Options for adding (activation) of } \\
\text { additional functions }\end{array}$ & 10 \\
\hline & - Back-up functions & 10 \\
\hline \multirow[t]{2}{*}{8} & Intelligent Electronic Devices characteristics & 100 \\
\hline & - IED class device functionality & 100 \\
\hline
\end{tabular}

\begin{tabular}{|c|c|c|}
\hline $\mathbf{N}$ & $\begin{array}{l}\text { Characteristic (group of characterizing } \\
\text { parameters) / Sub-characteristics }\end{array}$ & $\mathbf{E c} / \mathbf{r}_{\mathbf{i}}$ \\
\hline \multirow[t]{2}{*}{9} & Installation location conditions compatibility & 100 \\
\hline & $\begin{array}{l}\text { - Operability in the ambient conditions: } \\
\text { EMC, altitude, humidity, temp. range, etc. }\end{array}$ & 100 \\
\hline \multirow{4}{*}{10} & Compatibility with power supply & 60 \\
\hline & $\begin{array}{l}\text { - Power supply ratings (voltage, type of } \\
\text { voltage, range) }\end{array}$ & 20 \\
\hline & - Power consumption & 20 \\
\hline & - Internal power supply redundancy & 20 \\
\hline \multirow[t]{8}{*}{11} & Compatibility with peripheral devices & 100 \\
\hline & $\begin{array}{l}\text { - Measurement (instrumental) transformers } \\
\text { cores load }\end{array}$ & 20 \\
\hline & $\begin{array}{l}\text { - Availability and compatibility of the analog } \\
\text { I/Os }\end{array}$ & 20 \\
\hline & $\begin{array}{l}\text { - Availability and compatibility of the } \\
\text { discrete I/Os }\end{array}$ & 20 \\
\hline & $\begin{array}{l}\text { - Ratings of the input parameters values, } \\
\text { options for software adjustment }\end{array}$ & 10 \\
\hline & - Analog inputs range and compatibility & 10 \\
\hline & $\begin{array}{l}\text { - Permissible tolerances of the measurement } \\
\text { (instrumental) tr-s }\end{array}$ & 10 \\
\hline & $\begin{array}{l}\text { - Options for alternative sensors detachment } \\
\text { ("non-classical" voltage/current, etc. } \\
\text { measurement) }\end{array}$ & 10 \\
\hline \multirow[t]{7}{*}{12} & Firmware (software) & 100 \\
\hline & $\begin{array}{l}\text { - Software for IED configuration, option(s) } \\
\text { for preliminary configuration of all settings } \\
\text { ("online" and "off-line"), configuration } \\
\text { settings in a file, to be uploaded in IED(s). }\end{array}$ & 30 \\
\hline & $\begin{array}{l}\text { - Graphical presentation (visualization) of } \\
\text { the characteristics of the protection } \\
\text { functions adjustment }\end{array}$ & 20 \\
\hline & $\begin{array}{l}\text { - Functionality for recordings of events, } \\
\text { "oscillographic" records, time stamping. }\end{array}$ & 20 \\
\hline & $\begin{array}{l}\text { - Options for upgrade, expanding and } \\
\text { compatibility with other versions. }\end{array}$ & 10 \\
\hline & $\begin{array}{l}\text { - Compatibility of the software with OSs for } \\
\text { PCs. }\end{array}$ & 10 \\
\hline & $\begin{array}{l}\text { - Option to operate with the particular } \\
\text { language / alphabet. }\end{array}$ & 10 \\
\hline \multirow[t]{7}{*}{13} & Man - machine interface (MMI) characteristics & 60 \\
\hline & $\begin{array}{l}\text { - Display for visualization - type, } \\
\text { characteristics (LCD, TFT, LED, ...) } \\
\text { (backlight) }\end{array}$ & 10 \\
\hline & $\begin{array}{l}\text { - Signaling LEDs - number, configuration } \\
\text { options. Self-test status LED. }\end{array}$ & 10 \\
\hline & $\begin{array}{l}\text { - Control buttons (number, ergonomic, } \\
\text { durability) }\end{array}$ & 10 \\
\hline & $\begin{array}{l}\text { - Interfaces for the operator (Ethernet, USB, } \\
\text { RS232, RS485) }\end{array}$ & 10 \\
\hline & $\begin{array}{l}\text { - Protection device operation status indicator } \\
\text { (in service / internal fault, etc.) }\end{array}$ & 10 \\
\hline & $\begin{array}{l}\text { - Option to operate with the particular } \\
\text { language / alphabet }\end{array}$ & 10 \\
\hline \multirow[t]{2}{*}{14} & Interfaces to other systems & 60 \\
\hline & - Ethernet & 20 \\
\hline
\end{tabular}




\begin{tabular}{|c|c|c|}
\hline $\mathbf{N}$ & $\begin{array}{l}\text { Characteristic (group of characterizing } \\
\text { parameters) / Sub-characteristics }\end{array}$ & $\mathbf{E c} / \mathbf{r}_{i}$ \\
\hline & - Optical & 20 \\
\hline & - $\mathrm{RS} 232, \mathrm{RS} 485$ & 10 \\
\hline & - Other & 10 \\
\hline \multirow[t]{5}{*}{15} & $\begin{array}{l}\text { Service time, without necessity of maintenance } \\
\text { / servicing }\end{array}$ & 50 \\
\hline & $\begin{array}{l}\text { - Not necessary to perform periodic } \\
\text { maintenance (or for particular time } \\
\text { interval) }\end{array}$ & 20 \\
\hline & $\begin{array}{l}\text { - Not necessary to perform periodic test of } \\
\text { adjustments (or for particular time interval) }\end{array}$ & 10 \\
\hline & $\begin{array}{l}\text { Not necessary to perform periodic cleaning } \\
\text { of some components /or for particular time } \\
\text { interval/ }\end{array}$ & 10 \\
\hline & $\begin{array}{l}\text { Period of service, after which some } \\
\text { components have to be changed - internal } \\
\text { battery, surge arresters, filter capacitors in } \\
\text { power supply unit, air filters, fans, etc. }\end{array}$ & 10 \\
\hline \multirow[t]{6}{*}{16} & $\begin{array}{l}\text { Data / event registration; "oscillographic" } \\
\text { recorder functions }\end{array}$ & 70 \\
\hline & - Options for registration (recording) of data & 30 \\
\hline & $\begin{array}{l}\text { - Number of signals being recorded as } \\
\text { separate channels }\end{array}$ & 10 \\
\hline & - Number of records which can be stored & 10 \\
\hline & $\begin{array}{l}\text { - Records resolution (density of sampling } \\
\text { points) }\end{array}$ & 10 \\
\hline & $\begin{array}{l}\text { - Options for visualization and analysis of } \\
\text { the recorded data, supporting software tools }\end{array}$ & 10 \\
\hline \multirow[t]{2}{*}{17} & $\begin{array}{l}\text { Functionality to operate in } \\
\text { centralized/decentralized systems for } \\
\text { protection and control }\end{array}$ & 60 \\
\hline & - IEC 61850 compatibility (IEC 61870 , etc.) & 60 \\
\hline \multirow[t]{4}{*}{18} & $\begin{array}{l}\text { Functionality to receive (and redistribute) } \\
\text { centralized synchronization (GPS / IRIG-B, } \\
\text { other applicable master synchronization } \\
\text { signals) }\end{array}$ & 30 \\
\hline & $\begin{array}{l}\text { - Functionality to connect to common - site } \\
\text { data exchange systems }\end{array}$ & 10 \\
\hline & $\begin{array}{l}\text { - Functionality to connect to common - site } \\
\text { synchronization system }\end{array}$ & 10 \\
\hline & $\begin{array}{l}\text { - Functionality to connect to global } \\
\text { synchronization (GPS, other) }\end{array}$ & 10 \\
\hline \multirow[t]{5}{*}{19} & $\begin{array}{l}\text { Functionality to provide functions for Wide } \\
\text { Area Protection (WAP). EPS (Grid) level } \\
\text { protection functions; }\end{array}$ & 40 \\
\hline & $\begin{array}{l}\text { Protection functions for local measures to } \\
\text { achieve global EPS stability improvement, } \\
\text { limitation of the extension of fault } \\
\text { processes and unacceptable modes of } \\
\text { operation }\end{array}$ & 10 \\
\hline & $\begin{array}{l}\text { - Functionality for participation in Wide } \\
\text { Area Protection (WAP) }\end{array}$ & 10 \\
\hline & $\begin{array}{l}\text { - Functionality for participation in Wide } \\
\text { Area Measurement System (WAMS) }\end{array}$ & 10 \\
\hline & $\begin{array}{l}\text { - Functionality to receive / generate / } \\
\text { transmit signals for anticipated response }\end{array}$ & 10 \\
\hline
\end{tabular}

\begin{tabular}{|c|c|c|}
\hline $\mathbf{N}$ & $\begin{array}{l}\text { Characteristic (group of characterizing } \\
\text { parameters) / Sub-characteristics }\end{array}$ & $\mathbf{E c} / \mathbf{r}_{\mathbf{i}}$ \\
\hline \multirow[t]{2}{*}{20} & $\begin{array}{l}\text { Functionality for control of commutation } \\
\text { apparatus, interlocking between devices, etc. }\end{array}$ & 100 \\
\hline & $\begin{array}{l}\text { Functionality to replace or duplicate the } \\
\text { conventional relay/contact based } \\
\text { interlocking schemes with "fail-safe" } \\
\text { guaranteed design }\end{array}$ & 100 \\
\hline \multirow[t]{4}{*}{21} & $\begin{array}{l}\text { Modular design, options for upgrade and } \\
\text { extension }\end{array}$ & 20 \\
\hline & $\begin{array}{l}\text { Availability of spare analog / discrete } \\
\text { inputs. Optional functionality to integrate } \\
\text { signals from technological measurement } \\
\text { system (I\&C) }\end{array}$ & 10 \\
\hline & $\begin{array}{l}\text { - Compatibility between protection devices } \\
\text { from different generations (versions). } \\
\text { Similarity in the adjustment and } \\
\text { maintenance principles. }\end{array}$ & 5 \\
\hline & $\begin{array}{l}\text { - Availability of internal bus, which allows } \\
\text { adding additional expansion modules }\end{array}$ & 5 \\
\hline \multirow[t]{3}{*}{22} & $\begin{array}{l}\text { Service life, guaranteed under the specified } \\
\text { operating conditions }\end{array}$ & 50 \\
\hline & $\begin{array}{l}\text { Service life, guaranteed by the producer at } \\
\text { rated operating conditions, limiting } \\
\text { conditions }\end{array}$ & 40 \\
\hline & - Shelf life, storage conditions & 10 \\
\hline \multirow[t]{5}{*}{23} & $\begin{array}{l}\text { Guaranteed period for service, procurement of } \\
\text { spare parts, firmware update / support }\end{array}$ & 40 \\
\hline & - Period of provided maintenance & 10 \\
\hline & - Period of provided spare parts & 10 \\
\hline & $\begin{array}{l}\text { - Possibility modules to be replaced /repaired } \\
\text { on-site }\end{array}$ & 10 \\
\hline & $\begin{array}{l}\text { - Possibility modules to be replaced /repaired } \\
\text { in factory }\end{array}$ & 10 \\
\hline \multirow[t]{2}{*}{24} & Unauthorized access protection & 100 \\
\hline & $\begin{array}{l}\text { Protection against unauthorized access, } \\
\text { options for different levels of access, cyber } \\
\text { security aspects }\end{array}$ & 100 \\
\hline \multirow[t]{4}{*}{25} & Financial aspects & 30 \\
\hline & - Cost of equipment & 10 \\
\hline & $\begin{array}{l}\text { - Relative cost of the protection equipment in } \\
\text { respect to protected object }\end{array}$ & 10 \\
\hline & - Maintenance cost & 10 \\
\hline \multirow[t]{3}{*}{26} & References for application, other & 50 \\
\hline & $\begin{array}{l}\text { - References for positive operational } \\
\text { experience, other non-technical aspects }\end{array}$ & 50 \\
\hline & Total maximal rating points, Es & 2000 \\
\hline
\end{tabular}

* The reliability indices can be adapted in dependence of the particular application / data available.

The importance of the presented above protection device characteristics depends on the particular case of implementation. If "weighting coefficients" are used as multipliers for each group of parameters, they can have different relative distribution of the ranking values. In some cases not the devices themselves, but the accessories and the software (firmware) can have a decisive importance. The software is a key feature for the client in some 
cases. Some companies offer free firmware (for settings, download of records, etc.), some companies offer it as additional option, not free of charge. There are specific occasions, where even a single feature can be a serious obstacle for proper handling of the device: for instance - the device may comply with almost all requirements, but if there is no option for particular language this could be a critical obstacle for implementation. Some IED producers require payment for the software or part of the software functions. If these expenses are not counted in the "grand total" for protection device/system procurement, the financial comparison of possible options won't be precise. Depending on the scope of functionality, different software require different computing resources. Some firmware products are supplied to support wide spectrum of devices, but the software complexity can cause slow data transfer, inconvenience during work and extended requirements for $\mathrm{PC}$ resources. It is relatively common practice the vendor companies to provide basic operating platform, and the respective software modules for the particular type of protection devices (connectivity packages, product specific libraries) shall be additionally installed.

The software itself can provide different approaches for handling of the data, visualization screens, etc. The practice shows, that the software which provides informative and clear graphical presentation of the device settings facilitates the work process and reduces the probability for commissioning specialist / operational personnel mistakes.

\section{Theoretical results}

The scope of criteria presented in Table 1 gives a total maximal "rating" of 2000 points. The distribution of the ranking points between the respective sub-groups shall be revised for a particular case. The specifics of a particular project may impose some features of the selected devices to be more important in conditions of particular application. The content of the set of criteria may also vary.

In order to achieve realistic results by utilization of the proposed approach, it is important to have in mind not only the "quantity" of ranking points in general, but the balance between the accomplishments of the requirements by each position in general. Figuratively, this means that an option for device configuration can have a higher general score than other, but due

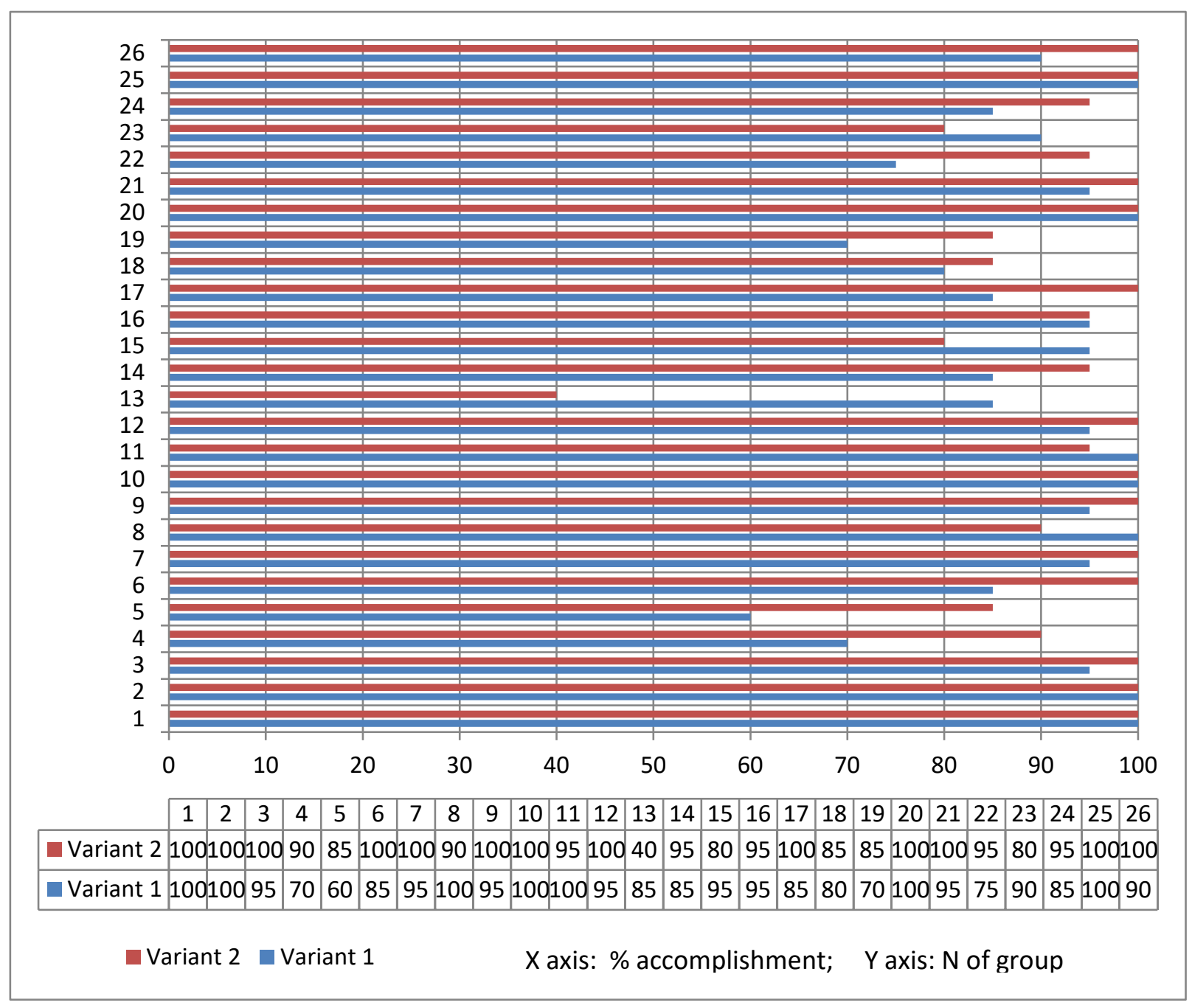

Figure 1. Example for comparison of hypothetical options for protection devices selection. 
to the facts that some criteria are maximally covered and other are not covered at all. Additional coefficients can be added in order to estimate the distribution of the values between the groups.

In Fig. 1 is presented an example for "application" of the proposed approach for estimation of digital protection devices applicability on basis of multiple characterizing parameters, based on two variants: "Variant 1" and "Variant 2". The "grand total" score for Variant 1 is $89.42 \%$ and for Variant 2 - 92.7\%. By absolute values - "Variant 2" shall be preferred. If a "threshold level" of $50 \%$ accomplishment is assumed, the screening of the individual groups of characteristics scoring indicates that for selection criteria N 13 - "Variant 2" fails with $40 \%$ accomplishment.

The systematized in such manner criteria based on the characteristics of the protection devices (or systems) can be used in two aspects:

- Estimation for equipment compliance to predefined requirements. The presence of particular feature of the protection device and/or compliance of the required parameter(s) brings the respective estimation (analysis of compliance) ranking points. After estimation of all of the features is formed a general (total) sum of ranking points (Es) is calculated. The sum of ranking points can be used as overall estimated criteria for the compliance of the respective device (system) with the preliminary defined criteria.

- Comparison of two (or more) options. The estimation can be made as every characteristic of the different optional types of equipment is compared to reference criteria. Possible approach is also to proceed with mutual comparison of the optional equipment characteristics. This approach can support the selection of optimal variant for protection devices (systems).

Some characteristics can be detailed further in the aspects of functionality to receive / generate / transmit signals for anticipated response. In case of occurrence of faults or other unacceptable processes, such functionality can help reducing the spread of disturbance in the EPS. Channels for accelerated processing of data for anticipated signals from local / remote power generations, priority dispatching centers communication, priority technological signals from the control systems of large concentrated power generations can be used. This option is related to the control systems of the respective objects as well.

Some of the protection devices design related features shall be estimated for a "period in the future", covering the expected service time. The presence of elements with rotation components like cooling fans, HDDs, can shorten the service life and/or impede the necessity of servicing. Typically the "relay protection" system do not have such elements, but indirectly they can depend on the operation of cabinet ventilation/cooling, power supply units, common SCADA servers, etc. The life span of built-in batteries for real-time clock and other back-up functions can also impose limitations on long-term operation of the electronic devices.

Some of the listed functionalities for protection devices practically are not applicable for electromechanical and solid-state devices. Eventual comparison between electromechanical and microprocessor devices is applicable only for specific cases.

\section{Conclusions}

The proposed approach for estimation of digital protection devices applicability on basis of multiple characterizing parameters can be used for comparison of alternative options of protection schemes.

The proposed set of criteria for IED applicability estimation, if intended for practical application, shall be "tailored" to the particular grid /grid operator/ utility operator specifics. Some advanced grid protection techniques like application of Phasor Measurement Units (PMU) are still not adopted in many regions, but the swift technology development indicates positive tendency [13]. Such functionality can also be included in the "extended version" of the example given in Table 1. The balanced and perspective designed protection systems will reduce a lot of problems like black-outs, power interruptions, power quality indices, etc. It shall be counted, that applying more sophisticated equipment imposes the necessity of increased installation, maintenance and equipment physical protection practices [14].

On the basis of such approach a procedure can be developed for both technical and economical evaluation of equipment applicability [15]. The proposed frame of criteria (the included in Table 1 characteristics) is based on some of the basic characteristics of the IEDs/protection devices. Extending the scope of criteria may lead to sophisticated ranking approach for detailed review of the characteristics of high technological products. In the scope of criteria the respective relevant IEC/EN/IEEE standards can be included [16,17].

Such approach may support the selection of optimal components for protection system and in the same time to give a sound justification of the selection [18]. If protection devices are selected on the basis of compromise-their limited functionality, insufficient options for upgrade, software limitations, etc., may impose shortages for the operation, maintenance and enhancing the system functionality in the future.

\section{References:}

[1] Remus Teodorescu, M. Liserre, P. Rodríguez, Grid Converters for Photovoltaic and Wind Power Systems, 2011 John Wiley \& Sons, Ltd. ISBN: 978-0-470-05751-3.

[2] Barkans J., Zalostiba D. Protection against Blackouts and Self-Restoration of Power Systems. RTU Publishing House, UDK 621.311.16, Riga, 2009.

[3] Learning from the Blackouts Transmission System Security in Competitive Electricity Markets, International Energy Agency (IEA) ISBN 9264 10961, 7 December 2005.

[4] S. Nick, H. Wetzel, C. Growitsch, The Costs of Power Interruptions in Germany - an Assessment in the Light of the Energiewende, Institute of Energy Economics at the University of Cologne (EWI), Working Paper, No 13/07, April 2013.

[5] Interim Report: Causes of the August 14th Blackout in the United States and Canada. U.S.-Canada Power System Outage Task Force. November 2003.

[6] The insurance implications of a cyber-attack on the US power grid. Lloyd's Emerging Risk Report - 2015. OSCE. Organization for Security and Cooperation in Europe.

[7] TEIAS, ENTSO-E. Report on Blackout in Turkey on 31 st March 2015. Final Version 1.0 Project Group Turkey, 21 September 2015.

[8] D. Novosel (chair) Performance of Relaying during Wide-Area Stressed Conditions, IEEE PSRC, WG C12, May 14, 2008.

[9] L. Shuran, D. Hui, G. Su. Analyses and Discussions of the Blackout in Indian Power Grid. Energy Science and Technology Vol. 6, No. 1, 2013, pp. 61-66.

[10] The Day the Sun Brought Darkness. NASA, https://www.nasa.gov/topics/earth/features/sun_darkness.html. 
[11] J.W.Wang, L.L.Ronga, "Cascade-based attack vulnerability on the US power grid," Elsevier, Safety science, vol. 47, no. 10, pp. 1332-1336, 2009.

[12] Avi Schnurr. Vulnerability of national power grids to electromagnetic threats: domestic and international perspectives. Energy law journal. Volume 34, No. 12013.

[13] Mladen Kezunovic, S. Meliopoulos, V. Venkatasubramanian, V. Vittal. Application of Time-Synchronized Measurements in Power System Transmission Networks, 2014 Springer, ISBN 978-3-319-06217-4.

[14] C. J. Schrijver, R. Dobbins, W. Murtagh, and S. M. Petrinec. Assessing the impact of space weather on the electric power grid based on insurance claims for industrial electrical equipment. AGU Publications. Research article 10.1002/2014SW001066, published online 8 JUL 2014.

[15] Mediha Mehmed-Hamza. Research of the sensitivity of the selective instantaneous overcurrent protection relays for terminals $20 \mathrm{kV}$. Journal of the Technical University Sofia, branch Plovdiv, "Fundamental Sciences and Applications", Vol. 14, 2009, International Conference Engineering, Technologies and Systems, pp. 251-256/in Bulgarian/.

[16] Organization for Security and Co-operation in Europe. Protecting Electricity Networks from Natural Hazards. 2016.

[17] ENTSO-E Subgroup "System Protection and Dynamics". Best Protection Practices For HV and EHV Transmission Systems of ENTSO-E CE Area Electrical Grids. Final version. 18 April 2012.

[18] ENTSO-E Subgroup "System protection and dynamics" Special protection schemes, March 2012. 